\title{
Evaluation of Community Empowerment Program Based on Community Satisfaction Index
}

\author{
Rizal Indra Priambada ${ }^{1, *}$, Rahmad Hidayat ${ }^{1}$, and Wahyu Purwanto ${ }^{1}$ \\ ${ }^{1}$ PT. Pertamina RU II Sungai Pakning, Bengkalis, Riau, Indonesia
}

\begin{abstract}
Abstrak. The community empowerment program is a program that is carried out with assistance and has a plan of up to five years. The empowerment program will be evaluated after one year of program implementation to see the impact of the program for the community. One of the programs is Berdikari Peat Village, which is an empowerment program for the Volunteer Fire Brigade called Masyarakat Peduli Api (MPA). One way to evaluate an empowerment program is to compile a Community Satisfaction Index (IKM). The concept of IKM will evaluate the program from the beginning of program planning, program implementation, to program exit so that the overall implementation of the program to the public is seen. This research was conducted with quantitative methods in the Berdikari Peat Village Kampung program which was carried out in Bukit Batu District, Bengkalis Regency, Riau Province. The conversion of SMI values varies from 25 to 100 with the symbol value A (Very Good) to D (Very Bad). The results showed a high Community Satisfaction Index in the empowerment program carried out by PT Pertamina RU II Sungai Pakning, with a score of 84.6 with a symbol of A.
\end{abstract}

\section{Introduction}

Scheme of People, Planet, and Profit is a concept held by the company in its business. Every company needs these three things to ensure the continuity of the company's business, in addition to pursuing business profits, the company also needs to build good relationships with the community and handle environmental problems properly. A system model to represent the link between an organization to its social responsibility responsiveness and responses and who identified internal and external affects of company's behavior [1]. One of the company's efforts to achieve its goals in terms of People and Planet is through the implementation of the Corporate Social Responsibility (CSR) program. CSR programs are a form of corporate social responsibility for the community and the environment around the company for business activities carried out. To be accountable to stakeholders and society at large, businesses have increased the issuance of corporate social responsibility reports explaining the impact of their activities on the environment and the use of natural resources [2].

\footnotetext{
* Corresponding author: rizalindra777@gmail.com
} 
Every company that is a State-Owned Enterprise (BUMN) and is an extractive company must carry out social responsibility programs based on law no. 40 of 2007 concerning Limited Liability Companies. Sachs, Ruehli, and Kern stated that CSR has roots in morality and underscore corporates' responsibility to not harm society and environment while positively contributing to the welfare of society and its stakeholders [3]. Not only as a form of responsibility for the existence of the law, the CSR program is build relationships with the community so that the company's business continuity can be guaranteed with a conducive condition of the surrounding community. To fully meet their corporate social responsibility enterprises should have in place a process to integrate social, environmental, ethical, human rights and consumer concerns in to their business operations and core strategy in close collaboration with their stakeholders [4].

Corporate social responsibility programs could be given as charity, infrastructure, capacity building, and community empowerment. The company not only provided material aid, infrastructure development and capacity building training, but assistance also needed during the program. Programs that are carried out with routine assistance every year are community empowerment programs, these programs usually have a five years program implementation plan. To be socially responsible implies that companies should consider all their responsibilities, and allocate sufficient funds and other resources to enable increases in capital spending, create jobs, and make contributions to the local and wider community through various forms of engagement and education [5]. Empowerment program is a program aimed at the community, especially vulnerable people who are given assistance both materially, adding capacity and assistance, also have the goal so that the community will become independent. This necessarily implies a vision that goes beyond philanthropy and donations, as this actions only bring temporary benefits, and in the long term, they may be harmful to social stability and the management of the local expectations [6].

Therefore the empowerment program is not a program that can be done instantly and with a short period of time. The program requires a process that takes up to several years to be able to achieve the goal, by changing the mindset of community. The ability of people to solve problems and organize themselves is the main goal to be achieved by the empowerment program. The main element in the process of community empowerment is the granting of authority and capacity to the community. It is necessary to see how the program works in the community and how the program impacts the community. One way to look at this is by program evaluation, evaluation can be done by calculating the Community Satisfaction Index of the program being run. Evaluation of the empowerment program can also be a proof for the company that has carried out the empowerment program well so that it can build relationships with the community and also manage the environment well.

\section{Method}

This research uses quantitative methods, primary data collection is done by survey techniques in the field to gather document. Survey were conducted with the beneficiary group or in this case the Kampung Gambut Berdikari's program. The data obtained is then converted into a score calculation in accordance with the community satisfaction index method which includes 11 variables, both from the socialization, the implementation process, to the impact of the program. Through these variables, The Community Satisfaction Index score will be obtained which can be categorized from very bad (1) to very good (4). The samples are 147 people from the total population of 4.848 .

The survey data obtained will be analyzed to determine the value and rating category of Community Satisfaction Index. Data analysis is a way of thinking related to systematic testing to determine the parts, looking for relationships between parts, and their relationship with the whole [7]. Analysis through the results of the evaluation will determine whether the 
program's evaluation is in accordance with the needs of the community and answer existing problems. For the following, the results of the community satisfaction index evaluation will be presented.

The evaluation carried out on the program must be objective and in accordance with the principles of evaluation so that the results obtained can be used as material for future decision making. Although the evaluation on the program is run by Pertamina itself, the results obtained must be in accordance with reality and can be justified. The research works is initially by making research instruments such questionnaires and interview guides. The research instrument was made in accordance with the variables and indicators used in the Community Satisfaction Index method, so that the research instrument included planning, implementing, and evaluating the impact of the program. After developing a work plan and determining the next research sample, the researcher will go to the field to collect data through surveys with the beneficiary groups. Data collection was also carried out by observation at the research location and also collecting secondary data. The data obtained will be analyzed and processed to be written in the community satisfaction index report.

The work method used is same as the research work method in general, but in this study technique needed to keep the data obtained remains objective. This needs to be done because the evaluation is carried out on the community empowerment program run by Pertamina itself. For this reason, researchers need to maintain the objectivity of the data to make sure that the results meet the aspects of reliability, objectivity and neutrality.

\section{Result and Discussion}

In accordance with the Community Satisfaction Index discussion, the three phases of the program under study are explained as follows:

\subsection{Planning}

Program planning consists of socialization and planning activities by involving the community. The outreach program invited several parties including the beneficiary community, the local government, and other private parties. The socialization in question is a step to provide an overview of the program that will be carried out in the next year. In addition, the socialization invited some of these parties to gather aspirations regarding the implementation of the program, according to Midgley's statement (2014) that community development also means providing opportunities for the community to maximize their potential, one of which is by facilitating and realizing community aspirations. In this program the socialization was carried out by holding a Focus Group Discussion (FGD) by inviting the Volunteer Fire Brigade called Masyarakat Peduli Api (MPA) group, the Fire Department, Police Department, Military Army, and the Village and District local governments. These parties are directly involved in the program and also deal with matters related to the program such prevention and resolving forest and land fires.

Program planning is done by preparing a Budget Draft. At this stage the budget draft is prepared in more detail by describing each activity that is available and adjusted to the available budget. The implementation time and budget will be informed to the parties and relevant stakeholders so that the details of the program are known by the parties. Program activities need to be planned with other stakeholders because they require collaboration and involvement of the parties during the implementation such as in joint training activities. 
Table 1. Community Satisfaction Index Score of Planning Stage Program

\begin{tabular}{|c|l|c|c|c|c|c|c|}
\hline \multirow{2}{*}{ No } & \multicolumn{1}{|c|}{ Stages } & $\begin{array}{c}\text { Integrated } \\
\text { Pineaple } \\
\text { Farm }\end{array}$ & $\begin{array}{c}\text { Volunteer } \\
\text { Fire } \\
\text { Brigade }\end{array}$ & $\begin{array}{c}\text { Forest } \\
\text { Honey }\end{array}$ & $\begin{array}{c}\text { Sekolah } \\
\text { Cinta } \\
\text { Gambut } \\
\text { Curriculum }\end{array}$ & $\begin{array}{c}\text { Peatland } \\
\text { Arboretum }\end{array}$ & $\begin{array}{c}\text { Average } \\
\text { Score }\end{array}$ \\
\hline 1 & Socialization & $85 \%$ & $84 \%$ & $86 \%$ & $76 \%$ & $86 \%$ & $83 \%$ \\
\hline 2 & Planning & $98 \%$ & $80 \%$ & $95 \%$ & $65 \%$ & $77 \%$ & $83 \%$ \\
\hline
\end{tabular}

The implementation of the community satisfaction survey at this stage is to reveal whether the socialization and planning made are in accordance with the interests and satisfaction of the relevant stakeholders. The survey conducted on the implementation of this stage showed a fairly high score of $83.0 \%$ in the socialization and $83.0 \%$ in the planning. This shows that the information provided by the company as a program planner has been distributed and well received by other stakeholders.

\subsection{Implementation}

After program planning information has been distributed and agreed by the relevant parties, the program will enter the implementation phase. In this stage the planned program will begin to be implemented by starting to carry out such as infrastructure development, training or other activities according to the agreed plan. In this process, implementers need to pay attention to the fund suitability and program implementation schedules. It really needs to be adjusted to the program planning before start implementing the program so the program that carried out is completed on schedule and does not exceed the budgeted funds.

Volunteer Fire Brigade development program is a program that has a work plan and strategic plan that has been set so it is very important to adjust its implementation to achieve the target. The result of community satisfaction index survey in this empowerment program is the community satisfied with the implementation, means that the implementation process, funding, and schedule are in accordance with the planning and have been able to achieve the desired target. According to the survey that has been done, this stage gets $88 \%$ value for the process, $82 \%$ for the suitability of costs, and $87 \%$ for the suitability of the schedule. Routine activities carried out every year in the MPA empowerment program are joint training, safetyman and fireman certification, MPA fast agile competitions, and MPA preneurship. With the high score, the score obtained shows that the activities mentioned above have been implemented according to the schedule and costs that were planned from the start.

The implementation phase of the program also requires appropriate facilities and infrastructure to support the success of the activity. Means for program implementation must also be included in the fund planning because every year implementation requires different facilities so it needs to be adjusted. The equipment and facilities needed in the program are planned in the budget draft at the beginning of the program so that the funds prepared are already in the amount. Equipment that needs to be purchased is usually a tool to support MPA activities in preventing and overcoming forest and land fires such as water pumping equipment, hoses, security equipment such as radios, wear pack covers, boots, helmets and so on. In addition to these tools, Pertamina as a partner also provides facilities and infrastructure to conduct activities such as joint training by providing training facilities along with other facilities such as fire trucks. Facilities and infrastructure are not only provided during program activities such as training, but also in firefighting activities. Personnel and equipment from Pertamina were also alerted to assist MPA in putting out fires. This is a form of corporate responsibility not only as a partner for MPA but also as a disaster prevention measure in the area around the company. 
Besides activities in terms of disaster, Pertamina also develop MPA groups to establish businesses as a form of improving the welfare of MPA members. The MPA Preneurship Program is a coaching program for the MPA to establish the MSME business. Some of the businesses owned by the MPA group include Pineapple Farming, Mushroom Cultivation, Catfish Cultivation, T-Shirts Printing, and also Forest Honey, and Peat Arboretum Tours. The activity is also supported by facilities and infrastructure provided by the company. The existence of MSMEs for the MPA group is enough to help them to be able to increase income since there is no salary in the MPA membership. This activity is not only as an economic improvement step but also as an activity that supports MPA activities such as hotspot patrols. The activities of forest honey farmers and pineapple farmers also indirectly support hotspot patrol activities, the land that used for pineapple farming was once burned because there was no activity and supervision because the land was not used before. With the presence of pineapple and forest honey, the community will be better in protect their land from fires, from a land that was less productive now being a valuable asset for the community. The existence of this peat arboretum tour is an environmental preservation step that is wrapped with the concept of educational tourism, the public can come and learn how to protect the peat ecosystem and study about peat ecosystem. This arboretum also provides education for students from elementary to tertiary level to provide knowledge about the peat ecosystem. The MPA Preneurship program is also developed and accompanied by the company so that the facilities and infrastructure are supported through program development every year. In a survey conducted in the community beneficiaries of the program showed a score of $85 \%$ in terms of program facilities. This shows that the community was quite satisfied with the infrastructure provided during the program.

In addition to the importance of program infrastructure, the empowerment program also requires regular assistance and carried out throughout the program. Assistance distinguishes the empowerment program from other programs such as capacity building, infrastructure development and charity. Program assistance is carried out while the program is ongoing and as long as the program has not reached the program exit stage so that assistance can last for years. The success of mentoring is oftenly a significant factor for the success of a program since the relationship between the beneficiary community and the company is more influenced by how the assistance is carried out.

Program assistance is usually carried out by facilitators who often meet directly with the beneficiary community. A facilitator must be able to build good relations with the community for the sustainability of the program, besides providing motivation for the beneficiary community groups it is also a task that must be able to be carried out by the facilitator. The key to community development is facilitating the community in applying the principles to guide a flexible series of actions that are appropriate for the situation of the community [8]. During the implementation of the program the facilitator becomes the person who needs to supervise and assist the program continuously so that it can ensure that the goals and targets are achieved as planned previously.

The program implemented is a disaster management program for forest and peatland fires so that the accompanying facilitator needs to be directly involved in processes such as firefighting and fire control. The program facilitator needs to show his concern for the program by not only accompanying the planned activities, but also must be present in every activity carried out by the MPA.

Aside from being a step to prevent forest fires through the MPA program, Kampung Gambut Berdikari program also aims to preserve ecosystems and improve the economy of communities in peat areas. Conservation of peat ecosystems is needed as a form of disaster management along with the programs that are implemented are in response to the forest and land fire disaster. The existence of pineapple and peat arboretum farming can benefit both the environment and the economy. Pineapple farming is carried out on previously unused and 
ex-fire land, so that with pineapple plants farmers feel more ownership and protect the land from fire. Aside from being a step to improve the economy for farmers, this program also aims to maintain soil conditions to be safe from the risk of fire [9]. Pineapple plants also don't absorb a lot of water so it doesn't cause drought in peat soils like oil palm, it is also a campaign for farmers in peat areas to reduce oil palm planting as a preventative measure for land drought that triggers fires. Peat arboretum is an ecotourism that is intended as an introduction to the community, especially students about the characteristics of peatlands so that it can be learned and known by public.

Table 2. Community Satisfaction Index Scoreof Implementation Stage Program

\begin{tabular}{|c|c|c|c|c|c|c|c|}
\hline \multirow[b]{2}{*}{ No } & \multirow[b]{2}{*}{ Stages } & \multicolumn{5}{|c|}{ Score } & \multirow[b]{2}{*}{$\begin{array}{l}\text { Average } \\
\text { score }\end{array}$} \\
\hline & & $\begin{array}{c}\text { Integrated } \\
\text { Pineapple } \\
\text { Farm }\end{array}$ & $\begin{array}{c}\text { Volunteer } \\
\text { Fire } \\
\text { Brigade }\end{array}$ & $\begin{array}{l}\text { Forest } \\
\text { honey }\end{array}$ & $\begin{array}{c}\text { Sekolah } \\
\text { Cinta } \\
\text { Gambut } \\
\text { Curriculum }\end{array}$ & $\begin{array}{l}\text { Peatland } \\
\text { Arboretum }\end{array}$ & \\
\hline 1 & Process & $90 \%$ & $84 \%$ & $91 \%$ & $87 \%$ & $87 \%$ & $88 \%$ \\
\hline 2 & Budget & $87 \%$ & $78 \%$ & $85 \%$ & $81 \%$ & $79 \%$ & $82 \%$ \\
\hline 3 & $\begin{array}{l}\text { Implementation } \\
\text { Schedule }\end{array}$ & $93 \%$ & $82 \%$ & $85 \%$ & $87 \%$ & $88 \%$ & $87 \%$ \\
\hline 4 & Tools & $90 \%$ & $80 \%$ & $82 \%$ & $87 \%$ & $85 \%$ & $85 \%$ \\
\hline 5 & Facilitator & $94 \%$ & $89 \%$ & $94 \%$ & $72 \%$ & $84 \%$ & $87 \%$ \\
\hline 6 & Utilization & $94 \%$ & $84 \%$ & $96 \%$ & $82 \%$ & $76 \%$ & $86 \%$ \\
\hline
\end{tabular}

With agriculture and ecotourism, in addition to economic benefits it also benefits to the environment so that now there is an environmentally friendly use of land, supervision of land by farmers, and the preservation of ecosystems through educational tourism. The results conducted on the beneficiary community showed that the community was quite satisfied with the benefits provided by the program both in terms of economy and environment.

\subsection{Evaluation}

The final phase after the program implementation is evaluation, which in this phase monitoring and evaluation from the program's impact will be carried out. The evaluation conducted at several aspects such as social, economic and environmental impacts. With this program, MPA is also included in the National Professional Certification Agency (BNSP) certification program for safetyman and fireman certification. The certification is a form of capacity building for MPA to support the firefighting activities during forest and land fires, besides that MPA can also use the certificate to work in companies at Bengkalis Regency. With the certification in the MPA program, some members have found work in the corporate sector as safetymen and firemen. This can be seen as an increase in people's welfare or economy due to the existence of the MPA program. The pineapple farm program also provides additional income for farmer groups that already have cooperatives with pineapple yields and processed pineapple products. Each year the pineapple harvest in a farmer cooperative can reach approximately 337.5 tons of fresh pineapple with grade A sold directly while grade $\mathrm{B}$ and $\mathrm{C}$ are usually processed into processed pineapple chips, dodol, syrup, and sweets. Pineapple plants have been planted in 14.5 hectares in a technique that the harvest can be done every month so that the cooperative gets income every month. Existing activities in the Kampung Gambut Berdikari program have brought the impact of economic improvement for the beneficiaries as evidenced by the additional income through economic activities and economic improvement through capacity building undertaken. The IKM survey conducted received a high enough score of $91 \%$, indicating that the community was quite satisfied with the economic impact felt by the program. In addition to several impacts on economic improvement, this program also has other impacts on the social life of the 
community. Social impacts in society can take the form of collaboration between groups and the form a forums or communities.

Table 3. Community Satisfaction Index Score of Evaluation Stage Program

\begin{tabular}{|c|c|c|c|c|c|c|c|}
\hline \multirow[b]{2}{*}{ No } & \multirow[b]{2}{*}{ Stages } & \multicolumn{5}{|c|}{ Score } & \multirow[b]{2}{*}{$\begin{array}{c}\text { Average } \\
\text { Score }\end{array}$} \\
\hline & & $\begin{array}{c}\text { Integrated } \\
\text { Pineapple } \\
\text { Farm }\end{array}$ & $\begin{array}{c}\text { Volunteer } \\
\text { Fire } \\
\text { Brigade }\end{array}$ & $\begin{array}{c}\text { Fores } \\
t \\
\text { Hone } \\
y\end{array}$ & $\begin{array}{c}\text { Sekolah } \\
\text { Cinta } \\
\text { Gambut } \\
\text { Curriculu } \\
\text { m }\end{array}$ & $\begin{array}{c}\text { Peatla } \\
\text { nd } \\
\text { Arbor } \\
\text { etum }\end{array}$ & \\
\hline 1 & $\begin{array}{l}\text { Economic } \\
\text { Impact }\end{array}$ & $97 \%$ & $88 \%$ & $95 \%$ & $94 \%$ & $82 \%$ & $91 \%$ \\
\hline 2 & Social Impact & $90 \%$ & $91 \%$ & $91 \%$ & $88 \%$ & $95 \%$ & $91 \%$ \\
\hline 3 & $\begin{array}{l}\text { Environment } \\
\text { Impact }\end{array}$ & $92 \%$ & $89 \%$ & $100 \%$ & $76 \%$ & $94 \%$ & $90 \%$ \\
\hline
\end{tabular}

The existence of the MPA Program creates cooperation and coordination between village MPA groups in Bukit Batu District, through this program also formed a forum for the MPA group namely the MPA Forum (Forkompa). MPA groups that are members of this forum are regularly scheduled to conduct joint exercises conducted with speakers from companies and other parties such as the Fire Department, Military Army, and Police. The MPA group is also scheduled to take part in the inter-MPA competition held annually by the sub-district government. With a variety activities involving all MPAs in the village, it creates an intergroup bonding relationship so that cooperation can be created. In some extinguishing activities the all MPA group coordinated with each other in land fires so that the MPA groups formed interconnected social networks. In accordance with the statement of Widhagdha [10], the impact of this program can be seen from the increase in community awareness of fire hotspot monitoring patterns, increased public awareness not to clear land by burning, the formation of Forkompa and decreasing the prevalence of ARI recorded in the Bukit Batu Health Center in the last two years.

This relationship formed as the impact of the lack of resources in the MPA group which requires cooperation to meet the needs to support group activities. Widhaghdha states that the relationships formed from the concept of bridging are social networks that connect between groups to at least exchange information and cooperate with each other [11]. The formation of social networks not only occurred in the MPA group but also in the Tunas Makmur Farmer Group, the group also began to collaborate with other groups or institutions in its business activities. In fulfilling orders, sometimes farmer groups also involve other institutions such as cooperatives and other village-owned enterprises (Bumdes) to participate in making ordered products. Members of farmer groups are also often invited to present materials for making handicrafts from pineapple leaves. Teshome (2014) states that it is true that sense of togetherness develops when people realize that they have a common problem and that they face difficult to manage it if they don't cooperate [12]. This shows the social impact not only for the farmer groups but also for other communities outside the farmer group. In this case the IKM survey score shows a $91 \%$ which indicates that the social impact of the program is already felt and is expanding not only for direct beneficiaries.

Kampung Gambut Berdikari Program was originally a program that departed from forest fire disaster (Karhutla), planning and initial goal of the program was disaster management. Forest and land fire is certainly an environmental problem that really needs to be considered its impact in damaging the environment. Environmental damage caused by forest and land fires not only affects environmental balance, but also social and economic community living in the areas. The livelihoods of most people in peat areas especially farmers have been the mostly affected due to environmental damage. Drought in peatlands makes communities no 
longer able to cultivate the land by burning or others, so that land cannot be easily planted. Vegetable and fruit farming also cannot be carried out due to lack of water in peatlands that why the only crop that can be planted is palm oil, in which this plants have a greater impact on peatland dryness. The existence of Integrated Pineapple Farming Program is a solution to overcome this problem, pineapple plants are plants that do not absorb much water and suitable for planting in peatlands. Pineapple planted land also has the role of firebreaks, a field that is easier to overcome if a fire occurs. This pineapple agricultural land becomes a fire prevention through the prevention of land drought and becomes an anticipatory step in the event of a fire, so that the impact of this program can cover both environmental and economic aspects. In line with the pineapple farming program, the MPA program is the vanguard in handling forest and land fires so the impact on the environment is the main objective of this program. The MPA program provides increased capacity, facilities, and better coordination for each village's MPA group, so that forest and land fire management can be done more effectively. One of the achievements of this program is to make the Sungai Pakning region free from forest fires or it can be said to be zero fire. With a significant reduction in hotspots and the occurrence of forest fires in the Sungai Pakning region, this area is free from the effects of smoke haze from land fires. Significant reduction in the occurrence of forest and land fires and haze is also a pretty good achievement in environmental aspects. Significant environmental impact felt by the community affected the results of the IKM survey conducted, in the aspect of environmental impact the program received a score of 90\%.The Berdikari Peat Village Program, which emerged from the issue of forest and land fires, managed to have an impact not only on the environment, but also on the social and economic impact of the community.

\section{Conclusion}

The survey conducted in the beneficiary communities of the Kampung Gambut Berdikari Program as a whole received score of 84.8. All of 5 programs included in Kampung Gambut Berdikari program also received a high score. Scores above 80 can be converted into the letter A, meaning that the community satisfaction index in this program gets an A. In accordance with the table above, there are four programs that get A score, another one program get a score of $\mathrm{B}$. This means that the community is quite satisfied with the programs run by the company and could feel the program's impact.

From 11 assessment indicators, all of them have received high scores and are included in the quadrant of maintaining performance so it means that they have entered a high success rate. The high score of Community Satisfaction Index is also influenced by the perceived impact of the program felt by the community, not only those directly involved in the program but also other communities outside the program. In accordance with the score summary table above, the scores obtained through the Community Satisfaction Index survey for impact of the program get a high score that reach above $90 \%$. The significant social, environmental and economic impacts felt by the community make the community feel that the program has succeeded in changing their situation.

\section{Reference}

1. Latapi Agudelo, M.A., Johannsdottir, L. \& Davidsdottir, B.A literature review of the history and evolution of corporate social responsibility, Int $J$ Corporate Soc Responsibility 4, 1 (2019) 
2. Khan, M., Lockhart, J.C. \& Bathurst, R.J. Institutional impacts on corporate social responsibility: a comparative analysis of New Zealand and Pakistan. Int J Corporate Soc Responsibility 3, 4 (2018).

3. Tamvada, M. Corporate social responsibility and accountability: a new theoretical foundation for regulating CSR. Int J Corporate Soc Responsibility 5, 2 (2020)

4. Strotmann, H., Volkert, J. \& Schmidt, M. Multinational companies: can they foster wellbeing in the eye of the poor? Result from an empirical case study, Int J Corporate Soc Responsibility 4, 2 (2019)

5. Masoud, N. How to win the battle of ideas in corporate social responsibility: the International Pyramid Model of CSR. Int J Corporate Soc Responsibility 2, 4 (2017)

6. Garcia-Chiang, A. Corporate social responsibility in the Mexican oil industry: social impact assessment as a tool for local development, Int J Corporate Soc Responsibility $\mathbf{3}$, 15 (2018)

7. M. Yusuf, Metode Penelitian, Kuantitatif, Kualitatif \& Penelitian Gabungan, Prenamedia Group (2014)

8. Amakye, K.G. Understadning community development in Sekyere Central District, Ghana. Bandung J of Global South 4, 5 (2017)

9. Rosilawati. Y, A. Dewi, Community Development as the Resolution to the Environmental Crisis in Kampung Jawa, Riau, Indonesia, IJPR, 24 (2020)

10. M.F. Widhagdha,Relasi Sosial dalam Praktik CSR, Arjuna Wijaya Karya (2019)

11. M.F. Widhagdha, dkk., CSR Pemberdayaan Masyarakat di Lahan Gambut, Arjuna Wijaya Karya (2018)

12. Teshome, E., Zenebe, M., Metaferia, H. et al. Participation and significance of self-help groups for social development: exploring the community capacity in Ethiopia. SpringerPlus 3, 189 (2014) 